\title{
Migrants and Refugees from Ghana and Haiti in Southern Brazil: Familial Constellations and Processes of Escape
}

\author{
Lucas Cé Sangalli, Maria do Carmo dos Santos Gonçalves
}

\section{Introduction}

In the face of the recent arrivals of migrants from different countries, the Brazilian state has provided several possibilities for their entrance and regularization. Some of these privileged specific groupings, such as the humanitarian arrival visas for Haitians and Syrians. Amongst the strategies for the regularization of residence in Brazil, one of the most common for those in vulnerable situations has been to claim refugee status. Applicants for refugee status in Brazil are entitled to a work permit and free access to the healthcare system, and they are allowed to legally send remittances while their refugee status application is being processed by the authorities. ${ }^{1}$

The diversity of regularization processes and specific provisions for certain groupings raises the question of how different procedures impact the selfpresentations of recently arrived migrants in Brazil. In our study, we also ask: What do different administrative framings do with recently arrived people in Brazil? How

\footnotetext{
1 This investigation was conducted within the framework of the research project "Biographies of migrants from Syria and West Africa in Brazil and in Germany - Processes of inclusion and participation in the context of so-called irregular migration" (RO 827/21-1; February 2019 - January 2022) funded by the German Research Foundation (DFG) under the supervision of Prof. Dr. Gabriele Rosenthal (University of Göttingen, Germany). 
do they influence the construction of life stories? How far does this contrast with the rules of discourses in their community in Brazil and in their home regions?

Often, research on the arrival of migrants and refugees has its focus on the present situation of people and their "integration" into the destination society. In this chapter, we go beyond a focus on the present dimension of the phenomena and look into life histories and the constellations which led to the decision to migrate. Our research questions explore this from a biographical and processual perspective (see Bogner/Rosenthal 2017). We reconstruct not only biographical but also collective processes which lead to migration, i.e. power imbalances amongst groupings and individuals within constellations prone to migration which appear in biographical we- and self-presentations:

By analyzing biographical we- and self-presentations it is possible to gain insights into the effectiveness of discourses and the unequal, asymmetric power balances in the particular historical-social and physical space in which the biographers live, or have lived. Such analysis makes it possible to reconstruct which groups or groupings have more sway than other groupings and individuals within a figuration of groupings - and in their discourses (Bogner/Rosenthal 2017: 35 f.).

To answer our questions, we discuss case studies of two migrants. We show how they present themselves in the light of the discourses a) at home; b) along their migration courses and c) in Brazil. We analyze the constellations that led to migration in their home countries and their situation in Brazil. These two cases, one of a migrant from Ghana and one of a migrant from Haiti, are taken from our sample of biographical narrative interviews (Rosenthal 2018; Schütze 2008a, b) with twentyseven people from the Caribbean, South America, Africa, and the Middle East, generated in different regions of Brazil in the course of our field research. The interviews were analyzed according to the method developed by Gabriele Rosenthal (2018) and her proposal for the separation of the analytical levels of self-presentation (presented life story) and the lived-through life (experienced life history).

Our analysis indicates that using the category "refugee" homogenizes the diversity of the movement of persons. At a synchronic level, the two people whose cases we discuss here could both be superficially described as refugees, in accordance with their legal status in Brazil. At a diachronic level, we have been able to reconstruct the genesis of their different life histories and to show what led them to present contrasting perspectives in relation to discourses they experienced at the time of the interviews.

Both cases are "exceptions" amongst Ghanaians and Haitians in Brazil because they were granted refugee status. ${ }^{2}$ In the case of Ghanaians, each application for refugee status is judged individually by the Brazilian state. Haitians, on the other hand, fall under the broader "privilege" of a humanitarian visa that homogenizes

2 According to the Brazilian Ministry of Justice (2018), only two Haitian nationals were recognized as refugees by the Brazilian state in recent years. Despite this, the wife of our interviewee and his children had refugee status at the time of the interview. 
them according to national belonging - and takes away their chance to be granted refugee status. The cases we present here are significant for any discussion of refugees and migrants in Brazil because they challenge homogenizing discourses. These are present even in academia, such as the discourse that attributes the migration of all Haitians to the 2010 earthquake in the country (Barros/Martins-Borges 2018; Nüske/Macedo 2019).

It is of course true that a large number of people from Haiti arrived in Brazil after the 2010 earthquake. In this context, the Brazilian government issued humanitarian visas to Haitians on the basis of a "natural disaster". Haitians had to apply for a visa in this category before entering Brazil - to keep migration regulated by the Brazilian state. As soon as they reached Brazilian territory, they were granted a regular residence permit. For Haitians who did not apply for this visa category before reaching Brazilian territory, the alternative way to regularize their situation - as in the case of all other migrants who entered Brazilian territory in an illegalized way was to file for refugee status. Often, they were not recognized as refugees but were allowed to stay in Brazil under other provisions (such as "cases not expressly provided for in the Brazilian legislation").

Although claiming refugee status is a common practice for the regularization of recently arrived people in Brazil, the majority of those who file for it are not recognized as refugees by the Brazilian state. This is the case not only for Haitians but also for many people from Ghana and other regions of West Africa. The case of Ghanaians differs from that of Haitians in Brazil and illustrates different strategies used by the Brazilian government to classify migrants. The increase in the arrival of people from Ghana and other West African countries had to do, amongst other things, with the window of opportunity created in 2014 during the FIFA World Cup. During this event, a visa-free policy for tourists was enforced by the Brazilian government. Ghanaians who entered the country during this period benefitted from this policy. After their three-month tourist visas expired, many remained and applied for refugee status to regularize their situation.

During our fieldwork in Brazil, we observed various regularization processes that began after people received the results of their application for refugee status. People who were not recognized as refugees often lived on a legalized basis in Brazil. Many fell into the category "cases not expressly provided for in the Brazilian legislation". In these cases, people had the opportunity to legally study, work, and access the healthcare system. After a period spent living in this legalized way in Brazil (which varied according to the circumstances), migrants, refugees, and asylees could file for Brazilian nationality.

Even though the cases we present in this chapter concern people who were recognized as refugees by the Brazilian state, our intention is not to essentialize the category of refugee in contrast to that of migrant. Instead, as our empirical data shows, our interviewees saw themselves as migrants rather than as refugees. This attitude was also evident in other interviews we conducted. 
We opted for the case studies of these two migrants because both arrived in Brazil at a similar time, were granted refugee status and had been living in Brazil for around five years at the time of the interviews. Karim Ishatu, ${ }^{3}$ a migrant from Ghana, presented himself as an African migrant, a belonging related to his familial constellation in his home region. Louis Honoré, a migrant from Haiti, presented himself as a hard-working migrant who faced various difficulties before reaching Southern Brazil.

The cases we present below show escapes from specific situations in familial constellations. The escapes took place in a context of societal and legal rules, as well as in certain political situations in the countries of origin and residence. These migrations cannot be explained exclusively in terms of escape from "poverty", collective violence or "natural disasters". Thus, we show how people escape familial constellations based on tradition, rules and norms in we-groups (in the terms of Norbert Elias 2008), and legal frameworks in their countries of origin or residence.

\section{Karim Ishatu: Inheritance Disputes, Responsibility for the Family, and Sexuality-Based Discrimination}

The case of Karim illustrates a process of categorization as refugee by Brazilian authorities grounded on alleged persecution due to sexual orientation or association with the LGBTI+ community in the country of origin. During the interview conducted at the end of 2018, Karim presented his escape from Ghana on these same grounds. However, the reconstruction of his life history shows that his escape was related to inheritance disputes in his familial constellation. Thus, his was not an "escape from poverty" as often attributed to "Africans" in public discourses in Brazil (see Mantovani 2020).

Let us first consider the rather difficult familial constellation of Karim, which comes primarily from the separation of his parents. Karim's familial constellation indicates a long history of migrations in different regions of West Africa. His maternal grandfather migrated from Togo to Southern Ghana. ${ }^{4}$ Karim's maternal grandparents were Ewe and Catholic Christians. His maternal family was spread through the Volta River and Southern Ghana regions, where his mother was born. His paternal grandfather migrated from Nigeria to Southern Ghana, where Karim's father was born. Karim's paternal family is Hausa and had both Muslims and Christians in the generation of his grandparents. His parents met around 1983 in Nigeria, where his father had moved from Ghana to work in trade. Karim's father had been married to two other wives before he married Karim's mother. He had three daughters with

\footnotetext{
3 The names of our interviewees are masked. We have altered all information that would allow their identification.

${ }^{4}$ Togo and Ghana are in this context to be seen as very close to each other, and even partly overlapping. Today especially the Ewe people are living both in Southern Ghana and Southern Togo. The modern border (created in 1957) divides their settlement area.
} 
the first wife. By the time he met Karim's mother, he had separated from his previous wives. In a context of expulsion of foreigners by the Nigerian military rulers (see Aluko 1985), Karim's mother moved back to the outskirts of Accra, where Karim was born in $1985 . .^{5}$ During this period, his father settled in Accra, where he married another wife. Karim's mother settled in a city in Southern Ghana close to Accra, where she sold products at a market. In the following years, she married another man, with whom she had several daughters. Karim was the only son of his mother and his father and would remain the only male child in both families.

Karim presented the refusal of his Christian mother to convert to Islam as the reason for the separation of his parents. He mentioned that this separation led to a constant dispute over him, the only son amongst fifteen siblings in his parents' marriages. Karim's childhood and youth were marked by the dislocation between his parents' houses in different cities. During his early childhood, he spent some time with his mother and her family in Togo. He was raised as a Catholic and attended Catholic schools in Southeastern Ghana. When he was about twelve years old, he moved to his father's house in Accra. They regularly went to a mosque, and Karim realized he was a Muslim, as he puts it. According to his presentation, his father's fourth wife attempted to poison him during the time he lived in his father's house. This seems to be a clear indication of the tensions between the different sections of his extended family or patrilineage. Karim remained the most privileged heir in the extended family of his father, who had several houses and properties. Both the paternal and maternal ethnic belongings of Karim - Hausa and Ewe respectively mean patrilineal inheritance in the case of his father's death. This meant his mother and sisters would be in a precarious situation upon Karim's father's or Karim's death (see Manuh 1997).

After finishing high school around 2002, Karim tried three times to join the Ghanaian Armed Forces without success. He lived between Accra and the city where his mother lived. He did technical courses to train as a mechanic and a painter. In the interview he did not go deeply into this period, which might be related to his closeness to Islamist communities. ${ }^{6}$ In about 2013, Karim was jobless in Accra and might have been involved with fundamentalist groupings which were gaining strength in Accra (see Aning/Abdallah 2013). During this time, he got involved in a conflict because he defended an allegedly gay friend. It is not clear if this happened inside his religious community. He mentioned that he was beaten, accused of being gay, and persecuted. In the face of this situation, his mother suggested to him to use the visa-free policy for the FIFA World Cup in Brazil in 2014 to migrate.

The "strange" relation between the alleged gender persecution and his mother's suggestion that he should leave the country becomes clearer when we consider the

\footnotetext{
5 As former British colonies, Ghana and Nigeria always had very strong ties to each other and there was a lot of immigration and temporary or labor migration in both directions.

${ }^{6}$ An external source informed us about the possible involvement of Karim in radicalized religious groups. It is unclear whether this might be related to his escape from Accra. But it means we must consider that his escape to Brazil might have been due to political persecution.
} 
inheritance disputes in his familial constellation. It can be assumed that he used the "persecution based on gender" as a basis for claiming refugee status in Brazil. On the other hand, his relatives might have used these accusations to hinder his access to properties he was entitled to. With regard to his position in the familial constellation and the inheritance disputes, he mentioned that his mother told him "his problem was not going away" and his family would continuously "create problems with him". His mother and some of his sisters (on the maternal side) collected money and Karim flew to São Paulo, Brazil. Thus, Karim's escape can be interpreted as a familial strategy worked out by his mother and sisters to keep Karim safe. Upon Karim's father's death and if Karim is alive, he will inherit several properties. This would not only secure a more stable position for him but also for his mother and sisters. If Karim dies before his father, then his mother and his maternal sisters will not be entitled to inherit his properties.

Also, in Accra there was a problem. I had a gay friend ok? // M: Uhum // for me it does not matter // M: yes // ((claps his hands)) gay, lesbian, it is your life. He is my friend. A man tried to beat him and I got angry and I fought with him but then they started to say that I too were the same // M: ahh // so, these things here ((shows scars)) // M: ah they hurt you here // ... so, I went to a place in Ghana where no one knows me [...] my mother said 'people here [in their city] already know about it, if you come back they will hurt you, kill you' ... so the few money she had, she used for this [for him to go to Brazil] (Karim, p. 13-14, 1. 19-27 and 1. 1-6). ${ }^{7}$

Karim arrived in São Paulo in July 2014. He then moved to Southern Brazil in August 2014 because he was informed that companies were looking for migrants to fill job positions there. He was welcomed by an institution of the Catholic Church, which helped him to find a job in a slaughterhouse ${ }^{8}$ and to file for refugee status. His claim was based on persecution for being accused of homosexuality. The situation of the LGBTI+ community in Ghana remains taboo in certain milieus and violence based on gender and sexuality is promoted by different groupings (see Baisley 2015). Moreover, same-sex intercourse is described as "unnatural carnal knowledge" in the Ghanaian Criminal code and can lead to legal prosecution (see Mendos 2019). ${ }^{9}$ Karim is one of the few migrants from Ghana who have been granted refugee status in Brazil. He was very surprised when he got a positive answer since all of his friends had their claims denied.

A claim for refugee status based on escape due to inheritance disputes most probably would not have resulted in the recognition of Karim as a refugee by the

\footnotetext{
${ }^{7}$ All interview quotes translated by the authors.

${ }^{8}$ Many of the recently arrived migrants in the Southern region have been hired to work in slaughterhouses and other companies (see Kingston 2016).

${ }^{9}$ In general, and in daily practice, Accra is not the most difficult or dangerous place for gays in Africa south of the Sahara (see Roxburgh 2014). However, it is certain that the issues of gay orientation and discrimination have become more important in Christian milieus in the past two decades - because of the fast growing (direct or indirect) influence of Pentecostal churches (see Meyer 2004). In addition, homosexuality is associated with witchcraft or harmful magic in some traditional religions (see Roxburgh 2014).
} 
Brazilian state, as we saw in other cases of West Africans we followed. Thus, Karim's strategy of stressing the danger of gender- and sexuality-based persecution might have been deliberate. The assumption that Karim, or somebody who acted as his advocate, used a purported gay orientation in order to gain refugee status might sound far too "rationalistic". Thus, the more plausible assumption is that he tried to evade this whole topic because he had been used to avoiding it for a long time (even if only his friend was gay and not he himself). He was probably not (fully) aware at the time that persecution due to sexual orientation could be a good "ticket" to gaining legal status as a refugee. He probably still had the internalized habit of avoiding the whole issue as far as possible.

In Southern Brazil, Karim had a relationship with a Brazilian woman, who was his work colleague. They split up after eight months together. During this period in 2014, he and other work colleagues were fired. They were all migrants from different regions (Haiti, Senegal, Ghana) who protested the company's work conditions. Karim was hired by another slaughterhouse for the next three years. Due to a repetitive strain injury associated with his job at the company, he demanded recognition of his rights relating to injuries sustained in the workplace. In the meantime, he was fired for just cause due to a conflict with a Brazilian colleague in an episode he described as racism. He presented it as if Brazilians were privileged to the detriment of foreigners in such situations.

After this episode in 2017, he moved to the city where he was living and was looking for a job at the time of the interview. Karim showed no interest in leaving Brazil, despite the fact that many of his friends had migrated to the United States. He played in a band with other people from Ghana and Senegal, and frequently visited a mosque. He received support from a Catholic institution and shared an apartment with three Sunni migrants from Ghana. His discourse was marked by religion, something associated not only with the figuration in which he had lived in Accra, but also with the community of people from West Africa he was part of in Southern Brazil. Karim thematized his refugee status and sexuality only when we asked about his claim for refugee status. His tendency not to talk openly about his presumed sexuality or that of his friends was associated both with the discourses in which he was socialized in West Africa and those in Southern Brazil.

His presentation in the interview was oriented towards a gendered notion of the role of men as providers in African families, a notion from specific discourses in Ghana. When he managed to accumulate some money, he sent it to his parents even though he was jobless at the time of the interview. He clearly separated his belonging to a we-group of "Africans" from his belonging to a we-group of "migrants" (in contrast to the second case presented in this chapter). The presentation of an "African" we-group has to do with the figurations in Southern Brazil, in which longestablished residents tend to subsume recently arrived Black people from Haiti and different regions of the African continent under the homogenizing they-image of "Africans". 
I am the third [child] in a family of fifteen women. I am the only man, so a lot of responsibility on me. Because we Africans, men take care of the household, so men have to leave the house to look for money to send to the family.... Women have many problems that women have, right? Things of women. For us, Africans, only the men can get out of the house to work to take care of your mother, of your family (Karim, p. 1, 1. 3 11).

In this context, Karim presented the treatment of women in terms of his African belonging. This belonging should be interpreted in association with his religious belonging. He appears to identify himself as a conservative Muslim, or to associate himself with a social milieu dominated by conservative religious groupings. This becomes clear especially if we consider that among Ghanaians it is very common, almost traditional, for women to work as traders and they often carry on long-distance trade with other districts or regions, or with neighboring countries in West Africa (see Wrigley-Asante 2018). On the other hand, Karim mentioned that at least some of his sisters worked. This might mean that he was the one in the familial constellation who got involved with a more conservative milieu. At first, Karim spoke of his responsibilities towards his family, but without mentioning inheritance disputes inside the familial constellation. He only mentioned them at the end of the interview, after we asked about his refugee claim procedure in Brazil.

The story of my refugee claim ... you know one thing there in Ghana (2) ... they don't like [homosexuals]. But there was also a problem with my father too because // M: ok // cause our family man get all the things. So, my father's family - because he has money - so if he dies today I can have everything and they can't [referring to his sisters and their husbands]. So now everyone has their eyes on me. So, if I die and there is not my father anymore, they can get all the money all the things. So, these problems we have with them. So, it is hard. I can't go there anymore in my country, in my state because if I go there, there will have a personal fight. They want to kill me because of property, houses, there's this problem there in Africa (Karim, p. 13, 1. 12-19).

In this sequence, it appears that not only homosexuality is a very conflictual issue in Ghana, but also the rules of inheritance, which differ from grouping to grouping. In the context of Ghana and other regions in West Africa, inheritance rules for women and children can generate conflicts between customary laws and the legal frameworks of nation-states (see Fenrich/Higgins 2001). If we embed Karim's familial constellation in the broader social and legal constellations of Ghanaian society, it becomes clear that the accusations regarding his presumed sexuality might have been used by family members as a way to foster his escape from the country so that other relatives would be in more privileged positions regarding inheritance. The high frequency of inheritance conflicts and conflicts associated with polygyny is not specific to Muslims in West Africa (see Falen 2008). The same conflicts arise among followers of traditional(ist) beliefs who practice polygyny. And given the high mortality rates of women in childbirth, at least until very recently (Ghana Statistical Service 2014), conflicts and conflictual figurations may result from relationships between 
the children or descendants of different wives, comparable to those that occur in monogamous families or communities (and not only in cases of divorce).

In this case study, we conclude that Karim felt more comfortable while keeping his family and the associated responsibilities at a "safe distance". At the same time, he exerted power by determining whom in the family had access to the money he sent to Ghana.

Only two of my sisters are married. The others work to help a bit. So, I also have money. I send it only to my father and to my mother [and not to siblings]. But they also work so this relieves a bit of my suffering too. But my responsibility - my mother, my father - sometimes I can take care of them ... I take the money for my mother and my father. Sometimes my father gives to other siblings too (Karim, p. 7, 1. 19-25).

This action temporarily "solved" the dispute inside his family constellation. It also put him in a more established position of provider and allowed him to stay away. The impact of remittances inside families is often found in other cases in Ghana (see Mazzucato 2008), and changes in position inside familial constellations through migration and control over remittances are well researched (see Brandhorst 2013). Karim's escape also enabled him to avoid pressure from his family to marry. Most probably, his family would have picked an "adequate" partner according to the rules of inheritance - so to say, to keep property inside the extended family. In the last contact we had with Karim in January 2020, he was dating a Brazilian woman from a nearby city. His future plans were to remain in Brazil and not to seek family reunion with his sisters and/or his mother, who helped him fund his migration. He manifested no intention of returning to Ghana.

In summary, the tensions and conflicts over inheritance in his family were one important reason for Karim's migration. A plausible view is that he tried to escape a situation where he was at risk of being poisoned. This seemed - at least to himself - to be a tenable interpretation of certain events. Most likely in this context, his sexual orientation (or that of his friends) had become an important issue giving rise to public discussions, accusations and the like. This might be associated with a recent change regarding public discourses on homosexuality nowadays in Ghana (see Asante 2020; Mohammed 2020). Accusations of homosexuality seem to have become a functional equivalent to accusations of witchcraft in conflicts surrounding inheritance. ${ }^{10}$ Because of poverty or great economic inequality inside polygamous families - for instance between the children of one wife and those of another, or even between the descendants of different brothers - conflicts over inheritance are often important and can become very serious. In the past, these would often include witchcraft accusations or poisoning, and the use of magicians and magical forces (see Gedzi 2009). In this context, the situation of Karim, as the one who would inherit all or most of his father's wealth, represents a constellation where inheritance disputes seem to be among the main driving factors that lead to migration.

\footnotetext{
10 The entanglements between gossip, rumors, and accusations of various kinds of violence in different societies has been explored in many studies (see Stewart/Strathern 2004: ch. 7).
} 


\section{Louis Honoré: Escape from Witchcraft, Political Dispute, and "Fight for Justice"}

We met Louis Honoré, from Haiti, for the first time in 2014 when we assisted him in his claim for refugee status and family reunion (his wife and children were living in the Dominican Republic at the time). Consequently, the interview with him in January 2019 was framed by his perception of us as people who assist migrants.

The case of Louis was framed by the Brazilian authorities as being associated with the kidnapping of his child in Haiti in the 2000s. Louis provided the authorities with newspaper articles from the period, as "proof" that he deserved to be granted refugee status. In the interview, he presented his migration from Haiti as his "fight for justice" in connection with the kidnapping. The reconstruction of his life history shows that this was also an escape from broader political conflicts, which were intertwined with Vodou services (sèvices), collective violence, and political corruption in the high ranks of the government in the Haitian capital. As we will show, his escape was not associated with the 2010 Haitian earthquake.

Louis was born in 1971 in the port city of Aquin, Southern Haiti. Its history is related to the plantation system established by French colonizers in the region (see Garrigus 1996). Its historical figuration has led to the presence of free Black families, descendants of enslaved families, and White families. ${ }^{11}$ As we will show, these belongings were referred to by Louis in his self-presentation. The region has been historically marked by the dislocation of different populations and illegalized activities in the Caribbean (see Garrigus 1996). This is associated with cultural and religious diversity even in the present. It is not clear if Louis' family was evangelical Protestant when he was born, or if Louis converted later in his life. His father left the family during Louis' early childhood. He moved to the French part of Saint Martin, a colonial territory still divided between the French Republic and the Kingdom of the Netherlands in the Caribbean. Louis' father lived on the island on an illegalized basis for more than ten years. Louis' presentation was oriented towards the migration of his father, which left him as the oldest son in his familial constellation. In the absence of his father, his mother married another man, with whom she had two more children. This led to the litigious separation of Louis' parents when he was eight years old. Due to the dispute and the poor living conditions of his mother, Louis moved to the house of his paternal uncle. During this period, he worked in the morning (an obligation from which his cousins were spared) and went to school in the afternoon. This had a profound impact on his formal education. His childhood and youth were marked by discrimination inside the familial constellation: "cause imagine I don't have a mother, I don't have a father" (p. 2, 1. 12-13). He spoke about his situation in his family using a we-image of enslavement.

11 We write Black and White with capital letters to stress their character as social categories related to racist practices of differentiation. In historical terms this applies to the Caribbean region, which is strongly marked by colonization and its outcomes even in the present. 
We stay there as slavery. You can imagine. All of us living in the house of my uncle. I have to wake up very early. [...] I have to prepare everything for him and his children. It is not easy to live in someone else's house (Louis, p. 2, 1. 6-12).

Louis left his outsider position in his familial constellation around the age of eighteen when he moved to the capital of Haiti, Port-au-Prince. During this period, his father moved back to Haiti and they were reunited. After living with his father for a while, Louis left to marry Nini. He had met her in the capital, where they built their own house. In 2000, when Louis was twenty-eight years old, soon after his father had passed away, a biographical event in their lives took on an explicitly sociopolitical dimension: their newborn baby was kidnapped inside a hospital in the capital. This led to mass protests and accusations against the former president Bertrand Aristide - who was running for the presidency - of being in charge of the kidnapping to use the child in a Vodou ${ }^{12}$ ritual for his election (see Deibert 2005).

The entanglements between Vodou (and religion in general), political corruption, and collective violence in Haiti are well documented (see Laguerre 1989; James 2012). Deibert (2005) suggests that, at least between 2000 and 2002, Aristide was involved with one of the most prominent gang leaders of Port-au-Prince. This gang leader was connected to the murder of several people, the abduction of children, and the alleged practice of Vodou services. The rumor about Louis' child being used in a Vodou ritual in the presidential palace was publicly broadcast, as shown by journalistic sources from the period. In this context, his escape happened in relation to a realm where politicians interact with the lwa (spirits) to gain power or remain in power, as presented in public discourses in Haiti. Louis himself did not present his escape from Haiti in terms of an escape from collective violence, nor did he explicitly explain it in terms of Vodou beliefs. This might be related to his socialization in a more conservative Pentecostal milieu. Discourses promoted in more conservative Pentecostal milieus tend to portray practices related to Haitian Vodou and AfroBrazilian religions in a pejorative style (see Rey 2010; Silva 2007). Louis presented himself as an evangelical and tried to distance himself from Vodou practices in the interview. It is not clear whether Louis and his family practiced Vodou and converted after the event or if they had already converted before the kidnapping. Conversion might have been a way of coping with their powerlessness in the face of the kidnapping of the child. It might have provided a framework for accepting the lack of a solution by state authorities for the case. Thus, Louis still hoped for "divine justice" in the future.

We also have to consider that other people believed that the child was turned into a "zombie", i.e., "enslaved" to serve the ones who sacrificed her for political power. She was killed by the perpetrator(s) as an offering to the lwa. In this case, the

12 Vodou refers to interactions between people and spirits (lwa), i.e., how the belief in these forces informs decisions and results in action. Non-believers are affected by the actions of believers (and thus by the $(w a)$. This notion avoids essentializing separate "religions" because "Catholicism, Vodou, and Protestantism ... co-define, mediate, and reproduce one another in the fluid, plural, and transnational religious landscape of Haiti, which extends ... to wherever Haitians reside" (Richman 2008: 4). 
quest for justice is both legal (recognition by the Haitian state of the atrocious act perpetrated by people associated with Aristide) and spiritual (so the child can "rest in peace"). If we consider Louis' belonging to an Evangelical we-group (both in Haiti and in Brazil), it is clear why it might be difficult for him to accept - or present the kidnapping of his child and their escape from Haiti as an escape from the lwa and witchcraft practices. If we consider the stigma ascribed by many Haitian Pentecostals to Vodou practices (also in transnational religious communities) and the association of these rituals with the "devil" (see Bertin 2011), it is possible to understand why Louis would not frame his escape exclusively in political terms.

Instead, Louis presented the abduction of his child and his quest for justice as the main motivation for him and his wife to leave Haiti. This topic remained the central theme of his presentation.

People say many things about my child. There are people that said it was President Aristide that took the child to sacrifice to stay in power (1). People say a lot of things about him in Haiti but the truth I don't know but he [Aristide] knows (Louis, p. 19, 1. 8-11).

This quotation shows how discourses by other people about the disappearance of his child ("people say many things about my child") are an open topic for him in the present. No one has been held responsible or punished for the act. No corpse has been found to be buried.

In April 2000, a journalist who supported Louis and Nini in the kidnapping case was brutally assassinated. Political instability was widespread in the wake of the elections (Deibert 2005). In this context, Louis and Nini escaped to Santo Domingo. In the capital of the Dominican Republic, they were recognized as refugees: "after we started to work things improved. It was peaceful there" (p. 9, 1. 8). Louis and Nini had three children in the Dominican Republic. They stayed in the country for about thirteen years. Their participation in Haitian Pentecostal churches might well have been a way of gathering support after their escape to Santo Domingo. Here, Louis and Nini were still learning to cope with the loss of their child. Their migration benefitted from a transnational network of Haitian Pentecostal churches in the Americas (see Brodwin 2003). In these churches, Louis and the family received religious and economic support. Conversion to evangelical Protestantism came with practical benefits, such as access to schools and adult education (see Munro 2015: 137), recurrent topics in Louis' self-presentation.

Haitians living in the Dominican Republic suffered from growing hostilities after the announcement of citizenship regulations during the 2000s. It is not clear which implications the 2013 decision by the Dominican Republic's Constitutional Court had for Louis and his family. This ruling rescinded birthright and "stripped thousands of ethnic Haitians of Dominican legal nationality" (Kingston 2016: 485). Even though they kept their right to stay in the country, threats of deportation, harassment from Dominican authorities, ethnic tensions, and xenophobia were widespread in the following years. This situation certainly influenced Louis' decision to leave the Dominican Republic, even if he did not expressly say so in the interview. This period 
in his self-presentation is important because of the relationship it has with the topic of "fighting for justice". Bulamah (2020: 2) writes about life in Santo Domingo during this period: "A constant feeling of uncertainty mediated the interactions between those people [Haitians or ethnic Haitians] and the Dominican state. Notions of abuso (abuse) and not having right to lajistis (justice) were common references when describing their actual situation". This shows that Louis' self-presentation was structured by the discourse in Santo Domingo, too. When Louis left the Dominican Republic, several other Haitians returned to Haiti (see Bulamah 2020). This was probably not an option for him and his family due to the politico-spiritual character of their escape.

Louis separated from his family and left the Dominican Republic around 2013. He presented his decision as his ongoing quest to seek for justice for his kidnapped child: "I need justice. I am looking in the Dominican Republic who can help me but I could find no one ... Until today I am looking for justice" (Louis, p. 8, 1. 6-8). Louis moved to Quito, Ecuador, which had a visa-free policy at the time and where one of his brothers lived. After the 2010 earthquake in Haiti, the Ecuadorian government welcomed Haitian citizens. Louis lost about eleven relatives in the earthquake, but he and his close family were not directly affected.

Despite his positive impressions of Quito ("the best place to live, people respect you”), Louis left for Northern Brazil around July 2014. He followed the Northern route through Bolivia and Peru and entered Brazilian territory undocumented. Soon after, he moved to Southern Brazil as migrants were being hired by companies to work in the region. There, with the assistance of a Catholic organization, he applied for refugee status. He did not consider any other specific possibility for regularization available to Haitian citizens. His decision to apply for refugee status should be analyzed in relation to his recognition as a refugee in the Dominican Republic. When Louis arrived in Brazil, he relied on his knowledge that refugee status is an advantage for people seeking family reunion. He had been socialized for several years in a discourse on refugees that gained important political dimensions in Santo Domingo. After being recognized as a refugee in Brazil, he filed an application to be reunited with his wife and children, who were still living in the Dominican Republic. They moved to Southern Brazil, where his wife gave birth to their fifth child. This allowed them to apply for naturalization on the grounds of having a Brazilian son.

Louis explicitly defined his belonging to a migrant we-group right from the beginning of the interview: "it is my pleasure to meet you to talk about my life, the life of a migrant" (p.1, 1. 1-2). On the level of his presented life story, he used "we" and "us" to refer to his experiences as if he were also reporting about other migrants. Even when referring to his childhood and to events he lived, so to say, "by himself", he presented them as a collective history of people on the move from his region in Haiti. He mentioned his refugee status only at the end of the interview when we explicitly asked about it. He presented his decision to apply for refugee status as a way of being politically active and fighting for justice for migrants, as well as for his rights regarding the kidnapping of his child in Haiti. He connected the loss of his 
child to his "activism", to himself as someone who fights for justice and education: "refugees are a person who has liberties and authority. When they arrive in a country, they can study or be politicians" (p. 19, 1. 21-23). These presentations show a clear connection with the power imbalances he experienced in Santo Domingo.

His future plans were connected to his ongoing "fight for justice". He mentioned that he would like to get justice in Haiti or Brazil and, if not possible there, then in the United States. A clearer image of what he meant by "getting justice" emerged when he contrasted his economic difficulties in Brazil with his perception that corruption crimes in the country are punished.

You have to ask them [the Haitian government] to give a solution for what happened [referring to the kidnapping]. The state, the state, the Republic of Haiti has to take the responsibility just like here in Brazil, the president [Lula] here that robbed, he is in prison. We have proofs [referring to the kidnapping of his child]. We have to go after justice (p. 19, 1. 1-4).

He presented himself not only in terms of the injustice of his child's abduction while he was in Haiti, but also in terms of the "fight for justice" discourse from the figuration in Santo Domingo. Furthermore, he presented himself in relation to a discourse from more established groupings in Southern Brazil. These groupings mainly descendants of long-established European families - are usually in favor of the arrest of former President Luiz Inácio "Lula" da Silva under alleged corruption charges. This indicates his alignment to dominant discourses enforced by more established groupings in Southern Brazil, which often tend to promote authoritarian measures in terms of punishment (especially against what they define as "corruption"). In the context of a community largely dominated by evangelical Pentecostals and long-established Catholic institutions, Louis probably did not feel comfortable talking about the kidnapping of his child in terms of "enslavement", that is, as if his child was used in the service of political power. He actively demanded from state institutions - in different nation-states - the identification and punishment of the perpetrators. The negative outcomes of law enforcement in Haiti were counterbalanced by the positive recognition of himself and his family members as refugees by the state in the Dominican Republic and in Brazil. The politico-spiritual character of Louis' escape from Haiti led him to seek justice in different groups. His participation in the Evangelical we-group might provide comfort in terms of the spiritual dimension, whilst his "activism" for a migrant we-group provides comfort on the political level.

In summary, Louis' situation represents a conflictual configuration marked by the entanglement of political disputes, collective violence, and the alleged use of witchcraft. His escape represents a constellation where individuals - and families are prone to migrate and interpret their migration in terms of religious and magical forces. However, these processes of escape - in the context of Haiti, but not restricted to it - are often also associated with political disputes, which may or may not lead to collective violence. Louis' migration course shows the benefits of a trans- 
national Haitian Evangelical network and the rules for what can be talked about and how to talk in this we-group, in this case, not speaking openly about the use of a family member in a Vodou ritual and her distancing from "paradise". Even if he did not believe in the lwa, he and his family suffered the very real consequences of practices associated with them. The period in Santo Domingo emerged latently in his presentation as a "fight for justice". After his arrival in Southern Brazil, he oriented his presentation towards the collective history of "hard-working migrants" in the region (see Santos/Zanini 2010). This is the dominant discourse promoted mainly by long-established groupings of descendants of European migrants.

\section{Conclusions}

Karim's case is that of a migrant who needs to keep at a safe distance from his family in his home country. This allows him to evade the pressures posed by the familial constellation for him to marry, the accusations relating to his presumed sexuality, and inheritance disputes. He copes with socio-familial responsibilities by remitting money to his parents. In other words, Karim is an example of migrants who have escaped from the family and its milieu but still feel strongly obliged to send remittances. Although he could choose to file for family reunion, he is not willing to bring his family to Brazil - in spite of the familial character of his migration.

Louis' case is that of a migrant who left his home country in the circumstances of the traumatic loss of his child in a context of political instability and who is still fighting for justice in his home country. In contrast to Karim's case, he did not escape from his close family but fought for family reunion (wife, children, and brothers). In this case, the knowledge acquired during his migration course was translated into political capital. He used his personal experiences to present himself in the name of a very broad wegroup of migrants.

The case studies presented show that if we had focused only on the self-presentations during the interviews, it would not have been possible to understand that these were cases of escape. Karim presented himself as an African migrant who used the window of opportunity created by the 2014 FIFA World Cup in Brazil. At no time did he mention that he escaped from conflicts in his familial constellation related to inheritance disputes. Louis presented himself as a migrant who was fighting for justice. He did not present his migration as an escape from political persecution and witchcraft beliefs associated with the death of his child. Only after the case reconstructions did we understand the processes of escape and their entanglement with familial constellations, political contexts, and societal and legal rules in these people's countries of origin and/or residence. According to the public discourse in Brazil, they come from so-called "safe" countries - Haiti and Ghana.

Our biographical reconstructions make it evident that they escaped from specific situations in their familial constellations relating to societal and legal rules, and from the political situation in their countries of origin. Thus, we cannot explain these 
migration movements only on the basis of escape from collective violence or "natural disasters". We also have to show how people escape familial constellations which are based on tradition, on the rules and norms in we-groups, and on legal frameworks in the countries of origin. We have to demonstrate how escapes from processes of collective violence can be interpreted by migrants as escapes from witchcraft, and how escapes presented as gender discrimination can be entangled with inheritance disputes.

Furthermore, it is necessary to contextualize such processes of escape in the rules of discourses, in the home country and in Brazil, which influence the selfpresentations. Especially in the Ghanaian case, we can say he left because of a burden of loyalty conflict, sexuality, inheritance disputes, or because he wanted to avoid marriage - topics he cannot talk openly about. Both men do not talk openly about persecution and their complicated familial constellations. They are aware that it is taboo to talk about sexuality, or religious practices, or to talk against their families or even to take no responsibility for family members - and this has to do with their socialization before their migration courses. Despite this, these things play a central role in their self-presentations in the present. If we had conducted only structured interviews with questions about why they left their home country, then it would not have been possible to reconstruct meanings of migration that are not manifest.

In addition, we have to consider the hegemonic and legal discourses in Brazil. These often give the impression that all Haitians suffered the direct consequences of the 2010 earthquake, and the poverty associated with it, and that this explains why people leave Haiti. Such a homogenizing they-image ignores familial constellations, political instabilities, the interrelation between family values and legal and political situations in home countries, and other forms of collective violence suffered by people on the move. Our results also challenge the notion that migrants from West Africa who have migrated to Brazil necessarily escaped from poverty or suffered persecution due to their sexual orientation. Even though the latter might give people higher chances of being recognized as refugees in Brazil, a reconstruction of the processes which led to their migration and a thorough analysis of their self-presentations in relation to discourses in Brazil and in the regions where they lived before their arrival show a different picture. This is a plea for not taking for granted categories used by international organizations and legal processes for the investigation of migratory phenomena. The relevancies of the subjects have to be reconstructed in their embeddedness within familial constellations and we-groups. Only then it is possible to explain escapes in terms of the rules of the we-groups people belong to, such as the intertwinement of political disputes and beliefs in witchcraft. Similarly, only after such thorough reconstructions is it possible to discover inheritance disputes in familial constellations and their entanglement with accusations of homosexuality. This is to say that many of the reasons presented in interview situations must be reconstructed in relation to discourses in we-groups and power figurations to make clear which constellations are more likely to lead to migration. It is necessary to go beyond a descriptive approach that remains on the superficial level of self- 
presentations in the present, and reconstruct the genesis of the processes in the diachronic dimension of the lived-through life (see Rosenthal 2018).

Our main finding is that migration and refugee courses can often best be explained in terms of the interplay between political and familial reasons and constellations. Thus, in case analyses we need to pay much more attention to the multiplicity of reasons that explain why people choose to leave so-called "safe" countries or countries associated with "natural disasters". Furthermore, it is important to see that what appear to be individual reasons are often also political. Situations relating to homosexuality, the discrimination associated with it, and its criminal prosecution are a political matter and not just a private one. The ethnic group of Karim expected him a) to present himself as the son of his father rather than the son of his mother, b) not to talk openly about his sexuality, and c) not to talk openly about conflicts in his family related to inheritance rules in the groupings he belongs to.

Based on our interviews in general and these two case reconstructions in particular, we assume that the rules of discourses and the societal and legal norms in the country of origin are stronger than those in the destination country. This can constitute a hindrance to participation in Brazilian society. Even after being granted refugee status by the Brazilian authorities, these migrants did not break the rules they had learned concerning what may or may not be openly spoken about, in other words they did not challenge the rules in which they were socialized in their home regions. Karim did not say he left the country because of his family and Louis did not talk openly about how he interpreted the kidnapping of his child in terms of the lwa, and how this led to his escape from Haiti. To some extent, to admit this would be to give up on his "fight for justice".

The interviewees presented themselves as migrants rather than as refugees. This is related to the dominant discourses in the destination country. In contrast to discourses in Europe, where references to refugees are widespread (see Krzyżanowski/Triandafyllidou/Wodak 2018), public discourses in Southern Brazil are still dominated by references to the history of the descendants of European migrants. The historical notion of "hard-working migrant" associated with the long-established groupings of descendants of European migrants still determines the selfpresentations of recently arrived people from West Africa and the Caribbean in the country. This justifies our argument that in order to adequately analyze the selfpresentations of recently arrived migrants and refugees in the present, we need to understand the rules of discourses in their we-groups and how they interrelate with figurations in the home community and the different rules of discourse in each grouping in the "destination" society.

Acknowledgments. Lucas Cé Sangalli received a doctoral grant from the German Academic Exchange Service (DAAD) that helped to partially fund this investigation. We wish to especially thank Dr. Artur Bogner and the editors of this volume for their valuable insights and comments on this article. 


\section{References}

Aluko, O. (1985): The Expulsion of Illegal Aliens from Nigeria. A Study in Nigeria’s Decision-Making. In: African Affairs, 84(337), 539-560.

Aning, K./Abdallah, M. (2013): Islamic Radicalization and Violence in Ghana. In: Conflict, Security \& Development, 13(2), 149-167.

Asante, G. (2020): Anti-LGBT Violence and the Ambivalent (Colonial) Discourses of Ghanaian Pentecostalist-Charismatic Church Leaders. In: Howard Journal of Communications, 31(1), 1-15.

Baisley, E. (2015): Framing the Ghanaian LGBT Rights Debate. Competing Decolonisation and Human Rights Frames. In: Canadian Journal of African Studies, 49(2), 383-402.

Barros, A./Martins-Borges, L. (2018): Reconstrução em Movimento, Impactos do Terremoto de 2010 em Imigrantes Haitianos. In: Psicologia: Ciência e Profissão, 38(1), 157-171.

Bertin, L. (2011): Haitian Protestant Views of Vodou and the Importance of Karactè within a Transnational Social Field. In: Journal of Haitian Studies, 17(1), 211-227.

Bogner, A./Rosenthal, G. (2017): Biographies - Discourses - Figurations.

Methodological Considerations from the Perspectives of Social Constructivism and Figurational Sociology. In: Rosenthal, G./Bogner, A. (eds.): Biographies in the Global South. Frankfurt a. M./New York: Campus, 15-49.

Brandhorst, R. M. (2013): Transnational Families in Cuba and Germany. On the Intersection Between Isolation, Restrictions, and Agency. In: Canadian Journal of Latin American and Caribbean Studies, 38(2), 254-278.

Brasil. Ministério da Justiça. Secretaria Nacional de Justiça (2018): Refúgio em Números. 3rd ed.

Brodwin, P. (2003): Pentecostalism in Translation. Religion and the Production of Community in the Haitian Diaspora. In: American Ethnologist, 30(1), 85-101.

Bulamah, R. (2020): Governing Mobility. Deportation and the Possibility of Life in Pequeño Haití, Santo Domingo. In: Papeles del CEIC, 1(229), 1-19.

Deibert, M. (2005): Notes from the Last Testament. The Struggle for Haiti. New York: Seven Stories Press.

Elias, N. (2008): Towards a Theory of Established-Outsider Relations. In: Elias, N./Scotson, J.: The Established and the Outsiders. Dublin: University College Dublin Press, 1-36. 
Falen, D. (2008): Polygyny and Christian Marriage in Africa. The Case of Benin. In: African Studies Review, 51(2), 51-74.

Fenrich, J./Higgins, T. (2001): Promise Unfulfilled. Law, Culture, and Women's Inheritance Rights in Ghana. In: Fordham International Law Journal, 25(1), 259-341.

Garrigus, J. (1996): Colour, Class and Identity on the Eve of the Haitian

Revolution. Saint-Domingue's Free Coloured Elite as Colons Américains. In: Slavery \& Abolition, 17(1), 20-43.

Gedzi, V. (2009): Principles and Practices of Dispute Resolution in Ghana. Ewe and Akan Procedures on Female's Inheritance and Property Rights. PhD thesis, Erasmus University Rotterdam.

Ghana Statistical Service (2014): 2010 Population \& Housing Census Report. Accra: Ghana Statistical Service.

James, E. (2012): Witchcraft, Bureaucraft, and the Social Life of (US)Aid in Haiti. In: Cultural Anthropology, 27(1), 50-75.

Kingston, L. N. (2016): Haitians Seeking Refuge in Brazil. In: Peace Review, 28(4), 482-489.

Krzyżanowski, M./Triandafyllidou, A./Wodak, R. (2018): The Mediatization and the Politicization of the "Refugee Crisis" in Europe. In: Journal of Immigrant \& Refugee Studies, 16(1/2), 1-14.

Laguerre, M. (1989): Voodoo and Politics in Haiti. London: Palgrave Macmillan.

Mantovani, F. (2020): Cansado de ouvir perguntas absurdas, imigrante cria camiseta 'África não é um país'. Folha de São Paulo. Online:

https://www1.folha.uol.com.br/mundo/2020/03/cansado-de-ouvir-

perguntas-absurdas-imigrante-cria-camiseta-africa-nao-e-um-pais.shtml $<06.03 .2020>$.

Manuh, T. (1997): Wives, Children, and Intestate Succession in Ghana. In: Mikell, G. (ed.): African Feminism. The Politics of Survival in Sub-Saharan Africa. Philadelphia: University of Pennsylvania Press, 77-95.

Mazzucato, V. (2008): The Double Engagement. Transnationalism and Integration. Ghanaian Migrants' Lives Between Ghana and The Netherlands. In: Journal of Ethnic and Migration Studies, 34(2), 199-216.

Mendos, L. (2019): State-Sponsored Homophobia. Geneva: International Lesbian, Gay, Bisexual, Trans and Intersex Association.

Meyer, B. (2004): Christianity in Africa. From African Independent to PentecostalCharismatic Churches. In: Annual Review of Anthropology, 33, 447-474. 
Mohammed, W. (2020): Deconstructing Homosexuality in Ghana. In: Nyeck, S. (ed.): Routledge Handbook of Queer African Studies. Abingdon: Routledge, 167-181.

Munro, M. (2015): Tropical Apocalypse: Haiti and the Caribbean End Times. London: University of Virginia Press.

Nüske, A./Macedo, M. (2019): Haitian Migration. The Subject Facing the $(\mathrm{Re})$ Encounter with the Excess. In: Psicologia USP, 30, 1-11.

Rey, T. (2010): Catholic Pentecostalism in Haiti: Spirit, Politics, and Gender. In: Pneuma, 32, 80-106.

Richman, K. (2008): A More Powerful Sorcerer. Conversion, Capital, and Haitian Transnational Migration. In: New West Indian Guide, 82(1/2), 3-45.

Rosenthal, G. (2018): Interpretive Social Research. An Introduction. Göttingen: Göttingen University Press. Online: https://doi.org/10.17875/gup2018-1103 $<15.07 .2020>$.

Roxburgh, S. (2014): Violence, Witchcraft and Mediation in Africa. A Comparative Study of Ghana and Cameroon. PhD thesis, University of Ottawa.

Santos, M./Zanini, M. (2010): As memórias da imigração no Rio Grande do Sul. In: Mneme, 11(27), 25-35.

Schütze, F. (2008a): Biography Analysis on the Empirical Basis of Autobiographical Narratives. How to Analyse Autobiographical Narrative Interviews. In: European Studies on Inequalities and Social Cohesion, 1/2, 153-242.

Schütze, F. (2008b): Biography Analysis on the Empirical Base of the Autobiographical Narratives: How to Analyse Autobiographical Narrative Interviews. In: European Studies on Inequalities and Social Cohesion, 3/4, 5 77.

Silva, V. G. d. (2007): Neo-Pentecostalism and Afro-Brazilian Religions. Explaining the Attacks on Symbols of the African Religious Heritage in Contemporary Brazil. In: Mana, 13(1), 207-236.

Stewart, P./Strathern, A. (2004): Witchcraft, Sorcery, Rumors, and Gossip. Cambridge: Cambridge University Press.

Wrigley-Asante, C. (2018): Women in Ties. Informal Social Networks Among Women in Cross-Border Trading in Accra, Ghana. In: Gender Issues, 35, 202 219. 